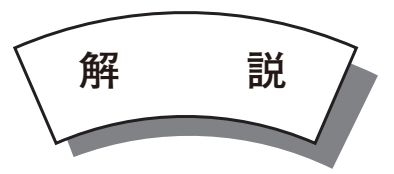

\title{
電子化物を利用したアンモニア合成用触媒材料の開発 \\ Development of Electride-Based Catalyst for Ammonia Synthesis
}

\author{
北野政 明* - 原亨和** ・ 細野秀 雄 $*, * *, * * *$ \\ Masaaki KITANO, Michkazu HARA and Hideo HOSONO
}

Key Words: $12 \mathrm{CaO} \cdot 7 \mathrm{Al}_{2} \mathrm{O}_{3}$, Electride, Catalyst, Ammonia Synthesis

\section{1. 緒 言}

アンモニアは、人類が最も多く生産する化学薬品の一 つであり、その生産量は全世界で年間 1.7 億トンを越える 勢いで増え続けている。世界では、尿素 $\left(\mathrm{CH}_{4} \mathrm{~N}_{2} \mathrm{O}\right)$ 、硫安 $\left(\left(\mathrm{NH}_{4}\right)_{2} \mathrm{SO}_{4}\right)$ 、硝安 $\left(\mathrm{NH}_{4} \mathrm{NO}_{3}\right)$ などの窒素肥料としてアンモ ニアは消費されており、70 億を超える人口を支えている。 20 世紀初頭にハーバー・ボッシュ等によってその合成方 法が確立され工業化された ${ }^{1)}$ 。さらに、アンモニア分子は 10 気圧、室温で液化が可能であり、その体積密度は液体 水素の 1.5 倍であることから貯蔵・運搬が容易な水素キャ リアとしても近年注目されている。アンモニア合成に対し て活性を示す触媒は、ハーバー・ボッシュ法で用いられる 二重促進鉄触媒の他に、ルテニウム、コバルト、オスミウ ム、レニウム、ニッケルなどが知られている ${ }^{2-5)}$ 。これらの 中でルテニウム触媒が、低温、低圧でのアンモニア合成に 対して最も優れた触媒性能を示すことが、尾崎萃、秋鹿研 一らによって見いだされた ${ }^{4)}$ 。ルテニウム触媒は、単独で 用いても効率よくアンモニアを合成することができず、ア ルカリ金属やアルカリ土類金属の酸化物（促進剂）を添加 することによって劇的に触媒性能が向上する。促進剤は、 ルテニウムを介して吸着窒素分子の反結合性軌道に電子を 与えることで、アンモニア合成の律速段階である窒素解離 を促進する働きがあるの。このルテニウム触媒によるアン モニア合成は、イギリスの Kellog 社によって工業化され、 Kellog Advanced Ammonia Process (KAAP 法) として知られ ている。

このように、アンモニア合成反応では、ルテニウムのよ うな活性金属種に対して電子を与える物質の存在が必要不 可欠である。したがって、アルカリ金属酸化物ではなく、 低い仕事関数を有するアルカリ金属を用いる方が、より電
子注入作用が期待できるが、アンモニア合成の反応条件下 では、アルカリ金属は安定に存在することができない7。 そこで我々は、安定な無機酸化物でありながら金属カリウ ムに匹敵する低い仕事関数を有する $\mathrm{C} 12 \mathrm{~A} 7$ エレクトライド に着目した。ルテニウムナノ粒子を担持した C12A7 エレク トライドを触媒として用いると、極めて高い効率でアンモ ニアを合成できることを見いだした ${ }^{8)}$ 。

\section{2. $12 \mathrm{CaO} \cdot 7 \mathrm{Al}_{2} \mathrm{O}_{3}(\mathrm{C} 12 \mathrm{~A} 7)$ 電子化物の特性}

$\mathrm{C} 12 \mathrm{~A} 7$ は、カルシウムやアルミニウムといった典型金属 の酸化物であり、アルミナセメントの構成成分として知ら れている。Fig. 1 にその結晶構造を示す。単位格子は 2 分 子で構成され $\left(2 \times \mathrm{C} 12 \mathrm{~A} 7=\mathrm{Ca}_{24} \mathrm{Al}_{28} \mathrm{O}_{66}\right)$ 、正に帯電した 12 個 のケージ（直径約 $0.5 \mathrm{~nm}$ ）が壁面を共有しながら 3 次元的

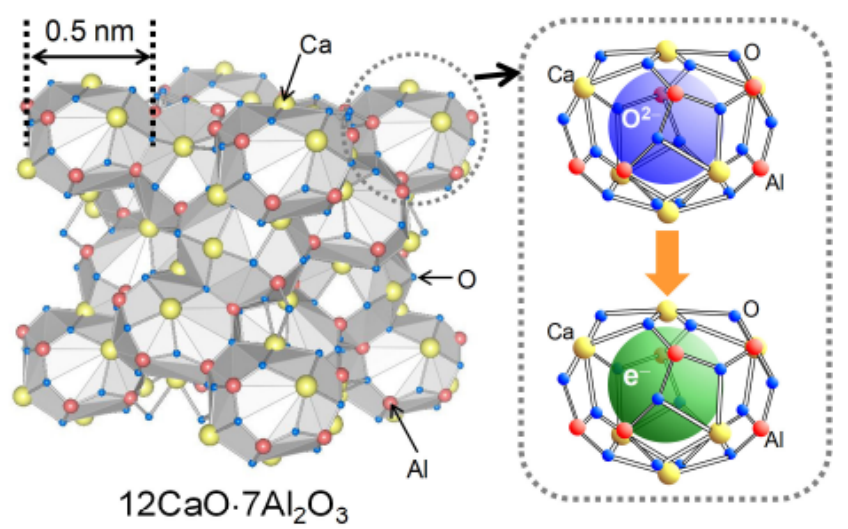

Fig.1 Crystal structure of $12 \mathrm{CaO} \cdot 7 \mathrm{Al}_{2} \mathrm{O}_{3} \cdot 12 \mathrm{CaO} \cdot 7 \mathrm{Al}_{2} \mathrm{O}_{3}$ consists of a positively charged lattice framework, $\left[\mathrm{Ca}_{24} \mathrm{Al}_{28} \mathrm{O}_{64}\right]^{4+}$ and two extra-framework anions, $\mathrm{O}^{2-}$. The expanded images show the cage incorporating a free $\mathrm{O}^{2-}$ ion and an electron.

*東京工業大学・元素戦略研究センター（２226-8503 神奈川県横浜市緑区長津田 4259）

Materials Research Center for Element Strategy, Tokyo Institute of Technology (4259 Nagatsuda, Midori-ku, Yokohama, Kanagawa, 226-8503 Japan) **東京工業大学応用セラミックス研究所（干 226-8503 神奈川県横浜市緑区長津田 4259）

Materials \& Structures Laboratory, Tokyo Institute of Technology (4259 Nagatsuda, Midori-ku, Yokohama, Kanagawa, 226-8503 Japan)

***東京工業大学 フロンティア研究機構（７226-8503 神奈川県横浜市緑区長津田 4259）

Frontier Research Center, Tokyo Institute of Technology (4259 Nagatsuda, Midori-ku, Yokohama, Kanagawa, 226-8503 Japan) 
に隣接し、他のケージとつながる開口径は約 $0.1 \mathrm{~nm}$ であ る。またその結晶骨格は、 $\left[\mathrm{Ca}_{24} \mathrm{Al}_{28} \mathrm{O}_{64}\right]^{4+}$ で表される ${ }^{9)} 。$ 方、残りの 2 つの酸素イオン $\left(\mathrm{O}^{2-}\right)$ は、ケージの壁の一部 を構成している6つの $\mathrm{Ca}^{2+}$ イオンによって配位されている が、その距離は同様な配位構造をとっている $\mathrm{CaO}$ 結晶 $(\mathrm{NaCl}$ 型）のそれよりも約 $50 \%$ 長くなっており、緩く束縛され ている。この性質にちなんでこの酸素イオンは“フリー酸 素イオン”と称せられている。C12A7 全体では、自由酸素 イオンの負電荷と結晶骨格の正電荷が電気的に補償されて いる。電子状態という観点から見ると、これらはいわゆる ワイドバンドギャップの物質であり、一般的には透明で非 磁性の絶縁体である。この物質を還元䨌囲気下高温で加熱 すると、 $\mathrm{O}^{2-}$ イオンをほぼ完全に電子 $\left(\mathrm{e}^{-}\right)$で置換すること が可能であり、 $\left[\mathrm{Ca}_{24} \mathrm{Al}_{28} \mathrm{O}_{64}\right]^{4+}\left(\mathrm{e}^{-}\right)_{4}\left(\mathrm{C} 12 \mathrm{~A} 7: \mathrm{e}^{-}\right)$と表すこと ができる ${ }^{10)}$ 。この時の電子濃度は $2.3 \times 10^{21} \mathrm{~cm}^{-3}$ である。 C12A7: $\mathrm{e}^{-}$は、電子がケージ内の特定結晶サイトを占有し、 結晶骨格とイオン結合した化合物である。こうした電子が 陰イオンとして機能する化合物は“電子化物”（エレクトラ イド）と名付けられている。

エレクトライド (Electride) とは日本語にすると、「電子化 物」であり、通常のイオン結晶でアニオンが占める位置を 電子が占めることによって構成されたイオン性の結晶のこ とを指す。このような材料は 1983 年に J. L. Dye らによっ て初めて合成された。 $\mathrm{Na}$ 等のアルカリ金属を液体アンモニ アに溶解させると、カチオン $\left(\mathrm{Na}^{+}\right)$と電子に解離し、それ ぞれがアンモニア分子に配位された状態で存在する。この ように生じた溶媒和電子は配位したアンモニア分子のお陰 でカチオンと再結合することなく安定に存在する。Dye ら はこの溶液にクラウンエーテルを溶かしてから、溶媒を揮 発させることで、カチオンをクラウンエーテルで包み込こ んで、電子との再結合を防いだまま結晶化させることに成 功した。これが最初のエレクトライド $\mathrm{Cs}^{+}(18 \mathrm{C} 6)_{2} \mathrm{e}^{-}$である (18C6 はクラウンエーテル $\mathrm{C}_{12} \mathrm{H}_{24} \mathrm{O}_{6}$ を表す $)^{11,12)}$ 。しかし、 これらの有機エレクトライドは、最も安定なものでも -40 ${ }^{\circ} \mathrm{C}$ 以上にすると分解してしまう極めて不安定な物質であっ た。一方、C12A7: e'は、陽イオンとして振る舞う結晶骨格が、 $\mathrm{Ca}^{2+}$ 及び $\mathrm{Al}^{3+}$ と $\mathrm{O}^{2-}$ 間の共有ないしイオン結合で構成され ているため、化学・熱的に安定な物質である。また、電子 を添加しない $12 \mathrm{~A} 7$ は絶縁体であるが、C12A7: e-は、金 属的な電気伝導 $\left(\sim 1500 \mathrm{Scm}^{-1}\right)$ を示す。金属的電子伝導性 は、3 次元的に隣接したケージが電子伝導帯 (ケージ伝導帯 : CCB）を形成し、添加された電子が、CCB 中を伝播するこ とに起因することが理論解析により示されている ${ }^{13)}$ 。また、 光電子分光測定により、金属カリウムに匹敵する低い仕事 関数 $(2.4 \mathrm{eV})$ を有することも明らかとなっている ${ }^{14)}$ 。この ように C12A7: e-は電子を外部に与えやすい性質を有して いる。一般的に電子を与えやすい（仕事関数の小さな）物 質は、アルカリ金属のように化学的にも熱的にも不安定で
あるが、この物質は安定であり大気中で容易に取り扱うこ とができる。なお、化学反応が生じる最表面までバルクと 同様に電子が入ったカゴが残る処理方法も既にSTMを駆 使した研究で確立されている ${ }^{15)}$ 。

\section{3. $12 \mathrm{CaO} \cdot 7 \mathrm{Al}_{2} \mathrm{O}_{3}(\mathrm{C} 12 \mathrm{~A} 7)$ エレクトライド担持 $\mathrm{Ru}$ 触媒に よるアンモニア合成}

C12A7: $\mathrm{e}^{-}$の合成方法は、様々な合成方法が確立されてい るが、本研究で用いた合成方法は以下の通りである。 $\mathrm{CaO}$ と $\alpha-\mathrm{Al}_{2} \mathrm{O}_{3}$ を $11: 7$ の比率で混合し、 $1300{ }^{\circ} \mathrm{C}$ で加熱するこ とで白色の複合酸化物 $\left(12 \mathrm{CaO} \cdot 7 \mathrm{Al}_{2} \mathrm{O}_{3}(\mathrm{C} 12 \mathrm{~A} 7)\right.$ と $\mathrm{CaO} \cdot \mathrm{Al}_{2} \mathrm{O}_{3}$ (CA) の混合物) が得られる。得られた粉末に金属 $\mathrm{Ca}$ を混ぜ、 真空下 $1100{ }^{\circ} \mathrm{C}$ で加熱することで黒色の粉体 C12A7: e-が合 成できる (Fig. 2) ${ }^{8)}$ 。

$\mathrm{Ru}$ 粒子は、物理混合した $\mathrm{Ru}_{3}(\mathrm{CO})_{12}$ と $\mathrm{C} 12 \mathrm{~A} 7: \mathrm{e}^{-}$を真空 下で加熱することで蒸着担持した。アンモニア合成反応は、 固定床流通式反応装置を用いて窒素と水素の混合ガス $\left(\mathrm{N}_{2}\right.$ : $\mathrm{H}_{2}=1: 3,60 \mathrm{~mL}$ min) を触媒層に流通させ、反応温度 320 〜 $400{ }^{\circ} \mathrm{C}$ 、圧力 $0.1 \sim 1.0 \mathrm{MPa}$ の条件下で行った。

Table 1 に $12 \mathrm{~A} 7: \mathrm{e}^{-}$および、様々な担体上に $\mathrm{Ru}$ を担 持した触媒によるアンモニア合成反応の結果を示す。 $\mathrm{Ru} /$ C12A7: $\mathrm{e}^{-}$は表面積が非常に小さい $\left(1 \sim 2 \mathrm{~m}^{2} \mathrm{~g}^{-1}\right)$ ため、 $\mathrm{Ru}$ の分散性が悪いことがわかる。にもかかわらず、 $\mathrm{Ru} / \mathrm{Al}_{2} \mathrm{O}_{3}$ や $\mathrm{Ru} / \mathrm{CaO}$ と比較して 10 倍以上高い触媒活性を示し、 $\mathrm{Ru}$ 担持活性炭に $\mathrm{Ba}$ 塩を添加した触媒 $(\mathrm{Ba}-\mathrm{Ru} / \mathrm{AC})$ や $\mathrm{Ru}$ 担持 $\mathrm{MgO}$ に $\mathrm{Cs}$ 塩を添加した触媒 $(\mathrm{Cs}-\mathrm{Ru} / \mathrm{MgO})$ に匹敵する活性 を示した。 $\mathrm{Ru}$ 触媒の中で最も高い触媒活性示す $\mathrm{Ba}-\mathrm{Ru} / \mathrm{AC}$

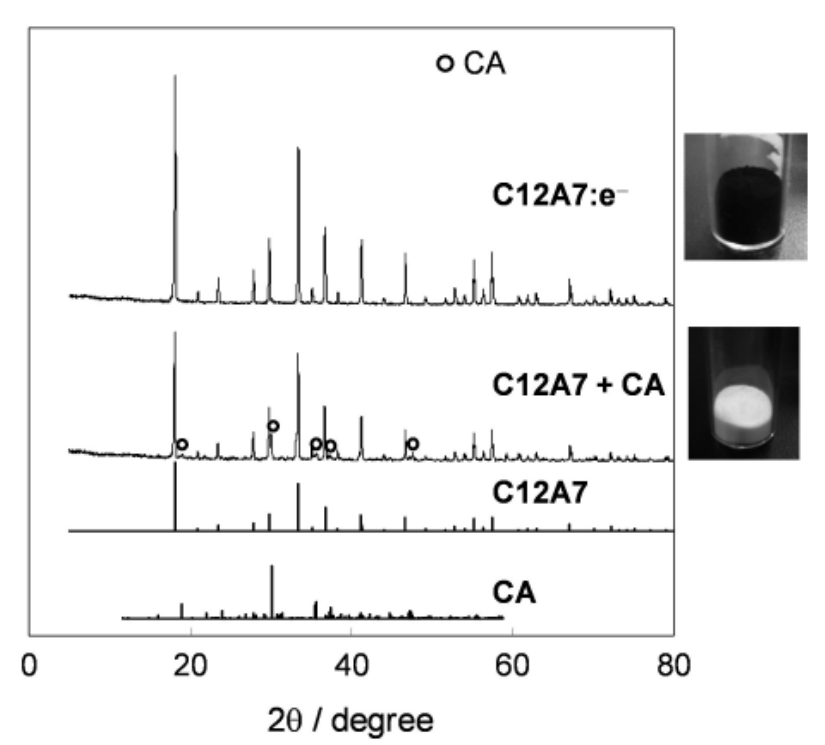

Fig.2 XRD patterns of $\mathrm{Ca}-\mathrm{Al}$ mixed oxide prepared at $1300 \quad{ }^{\circ} \mathrm{C}$ and C12A7: $\mathrm{e}^{-}$. Standard diffraction patterns of $12 \mathrm{CaO} \cdot 7 \mathrm{Al}_{2} \mathrm{O}_{3}$ $(\mathrm{C} 12 \mathrm{~A} 7)$ and $\mathrm{CaO} \cdot \mathrm{Al}_{2} \mathrm{O}_{3}(\mathrm{CA})$ are provided for reference. 


$$
\text { スマートプロセス学会誌 第 } 2 \text { 巻 第 } 6 \text { 号（2013 年 } 11 \text { 月） }
$$

Table 1 Catalytic performance of Ru catalysts on various supports for ammonia synthesis.

\begin{tabular}{|c|c|c|c|c|c|c|c|}
\hline Catalyst & $\begin{array}{l}\text { Surface } \\
\text { area } \\
\left(\mathrm{m}^{2} \mathrm{~g}^{-1}\right)\end{array}$ & $\begin{array}{c}\mathrm{Ru} \\
\text { loading } \\
\text { (wt\%) }\end{array}$ & $\begin{array}{c}\text { Dispersion } \\
(\%)\end{array}$ & $\begin{array}{c}\text { Particle } \\
\text { size }(n m)\end{array}$ & $\begin{array}{c}\mathrm{NH}_{3} \text { synthesis } \\
\text { rate } \\
\left(\mu \mathrm{mol} \mathrm{g}^{-1} \mathrm{~h}^{-1}\right)\end{array}$ & $\operatorname{TOF}\left(\mathrm{s}^{-1}\right)$ & $\begin{array}{c}\mathrm{Ea} \\
(\mathrm{kJ} \\
\left.\mathrm{mol}^{-1}\right)\end{array}$ \\
\hline $\mathrm{Ru} / \gamma-\mathrm{Al}_{2} \mathrm{O}_{3}$ & 170 & 6.0 & 12.5 & 10.6 & 51 & 0.0002 & - \\
\hline $\mathrm{Ru} / \mathrm{CaO}$ & 3 & 1.5 & 4.9 & 27.2 & 158 & 0.006 & 120.1 \\
\hline \multirow{2}{*}{ Ba-Ru/AC } & 310 & 1.0 & 25.2 & 5.3 & 148 & 0.003 & 88.8 \\
\hline & 310 & 9.1 & 14.3 & 9.3 & 2228 & 0.003 & 72.5 \\
\hline \multirow{2}{*}{ Cs-Ru/MgO } & 12 & 1.0 & 50.3 & 2.7 & 2264 & 0.013 & 85.8 \\
\hline & 12 & 6.0 & 18.6 & 7.2 & 3353 & 0.008 & 73.0 \\
\hline $\mathrm{Ru} / \mathrm{C} 12 \mathrm{~A} 7: \mathrm{O}^{2-}$ & $1 \sim 2$ & 1.2 & 3.4 & 39.2 & 546 & 0.038 & 104.6 \\
\hline \multirow{4}{*}{$\mathrm{Ru} / \mathrm{C} 12 \mathrm{~A} 7: \mathrm{e}^{-}$} & $1 \sim 2$ & 0.1 & 15.6 & 8.5 & 715 & 0.161 & 53.6 \\
\hline & $1 \sim 2$ & 0.3 & 4.1 & 32.9 & 1027 & 0.274 & 40.0 \\
\hline & $1 \sim 2$ & 1.2 & 3.2 & 41.3 & 2757 & 0.197 & 49.1 \\
\hline & $1 \sim 2$ & 4.0 & 2.0 & 68.5 & 2122 & 0.076 & 56.0 \\
\hline
\end{tabular}

${ }^{a} \mathrm{NH}_{3}$ synthesis conditions: catalyst $(0.2 \mathrm{~g})$, synthesis gas $\left(\mathrm{H}_{2} / \mathrm{N}_{2}=3\right.$, flow rate: $\left.60 \mathrm{~mL} \mathrm{~min}{ }^{-1}\right)$, reaction temperature $\left(400^{\circ} \mathrm{C}\right)$, pressure $(0.1 \mathrm{MPa})$.

や $\mathrm{Cs}-\mathrm{Ru} / \mathrm{MgO}$ では、 $\mathrm{Ba}$ や $\mathrm{Cs}$ の酸化物から $\mathrm{Ru}$ への電子注 入により反応が促進されることが知られている ${ }^{16,17)}$ 。一方、 $\mathrm{Ru} / \mathrm{C} 12 \mathrm{~A} 7: \mathrm{e}^{-}$は、ケージ内に電子が入っていない触媒 $(\mathrm{Ru} /$ $\mathrm{C} 12 \mathrm{~A} 7: \mathrm{O}^{2-}$ )の 5 倍を越える触媒活性を示すことから、ケー ジ内の電子によってアンモニア合成反応が大幅に促進され ていることがわかる。またTable 1 の各担体における Ru サイトの TOF では Ru/C12A7: $\mathrm{e}^{-}$が圧倒的に高い值を示し ており、C12A7: $\mathrm{e}^{-}$上の $\mathrm{Ru}$ の反応効率は他を凌駕すること が明らかになった。さらに、C12A7: $\mathrm{e}^{-}$上の $\mathrm{Ru}$ 担持量を変 化させると、担持量が $4 \sim 0.3 \mathrm{wt} \%$ へと減少するにつれて TOF 值が大きく向上した。このことから C12A7: $\mathrm{e}^{-}$との界 面付近の $\mathrm{Ru}$ ほど電子注入の効果を強く受け、高い触媒活 性を示すことが示唆された。 $320 \sim 400{ }^{\circ} \mathrm{C}$ の温度領域で各 触媒の活性化エネルギーを求めると、ほとんどの触媒が 73 〜 $120 \mathrm{kJmol}^{-1}$ 程度であるのに対し、 Ru/C12A7: $\mathrm{e}^{-}$は、それ らのおよそ半分の值を示すことがわかる。これは、アルカ リ金属酸化物のような材料よりも C12A7: $\mathrm{e}^{-}$の方が Ru 触媒 への電子注入効果が高いため、アンモニア合成の律速段階 である $\mathrm{N}_{2}$ の解離を大きく促進しているためであると考え られる。

この触媒の特筆すべき特長の一つとしては加圧条件下で の効率的なアンモニア生成が挙げられる。平衡論的には原 料ガスの圧力が増加するほどアンモニア生成速度は増加す るが、多くのルテニウム触媒では Fig. 3 に示すように圧力 の上昇が反応速度の増加に繋がらない。これは、ルテニウ ム表面が解離吸着した水素原子によって覆われる現象（水 素による被毒効果) によって、窒素の解離が阻害されるた めである ${ }^{18)}$ 。一方、 $\mathrm{Ru} / \mathrm{C} 12 \mathrm{~A} 7: \mathrm{e}^{-}$では、圧力に依存して触 媒活性が大きく向上しており (Fig. 3)、C12A7: e-に固定化

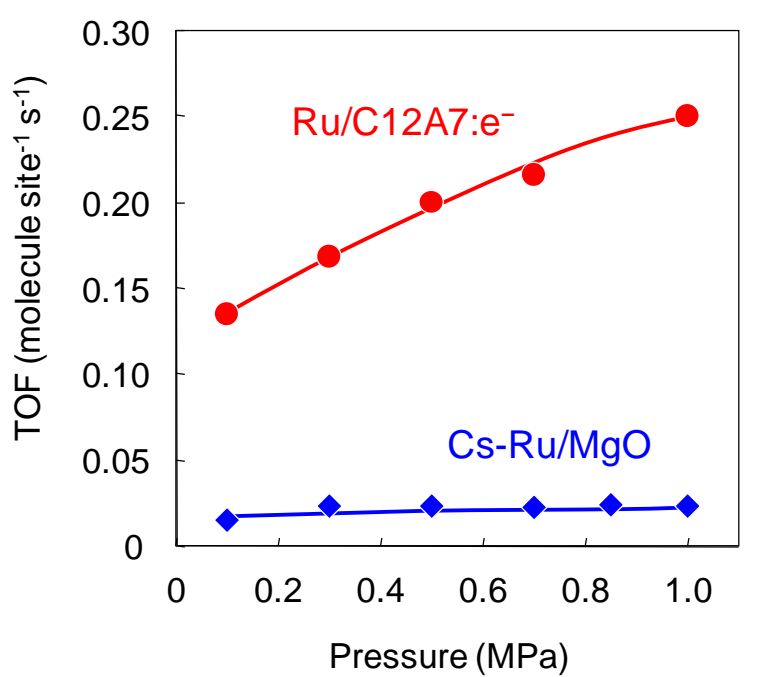

Fig. 3 TOFs for high-pressure ammonia synthesis over $1 \mathrm{wt} \% \mathrm{Ru} /$ C12A7: $\mathrm{e}^{-}$and $6 \mathrm{wt} \% \mathrm{Cs}-\mathrm{Ru} / \mathrm{MgO}$. Reaction conditions: catalyst, $0.2 \mathrm{~g}$; synthesis gas, $\mathrm{H}_{2} / \mathrm{N}_{2}=3$ with a flow rate of $60 \mathrm{~mL} \mathrm{~min}{ }^{-1}$; temperature, $360{ }^{\circ} \mathrm{C}$.

された Ru触媒は水素被毒を受けにくいことがわかる。

アンモニアは液化して回収する方が工業的に有利である ため、ある程度加圧した条件（10 気圧程度）で効率よく働 く触媒は実用的観点からも大きな意義をもつ。Fig. 4 に Ru/ C12A7: $\mathrm{e}^{-を}$ を加圧条件下で長時間反応を行った結果を示す。 時間に対して直線的にアンモニアが生成し、75 時間経過し ても触媒活性はほとんど変化せず、 Ru/C12A7: e-は安定し てアンモニアを合成できる触媒であることが示された。ま た、C12A7: $\mathrm{e}^{-}$のケージ内の 1 つの電子が窒素 1 分子に対 


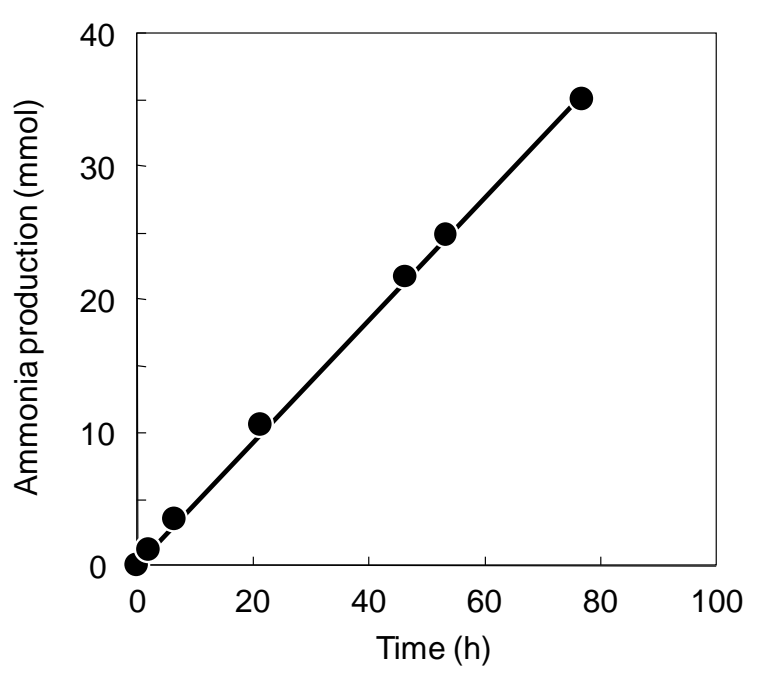

Fig. 4 Time course of ammonia formation over $1 \mathrm{wt} \% \mathrm{Ru} / \mathrm{C} 12 \mathrm{~A} 7: \mathrm{e}^{-}$. Reaction conditions: catalyst, $0.2 \mathrm{~g}$; synthesis gas, $\mathrm{H}_{2} / \mathrm{N}_{2}=3$ with a flow rate of $60 \mathrm{~mL} \mathrm{~min}^{-1}$; temperature, $360{ }^{\circ} \mathrm{C}$; pressure, $1.0 \mathrm{MPa}$.

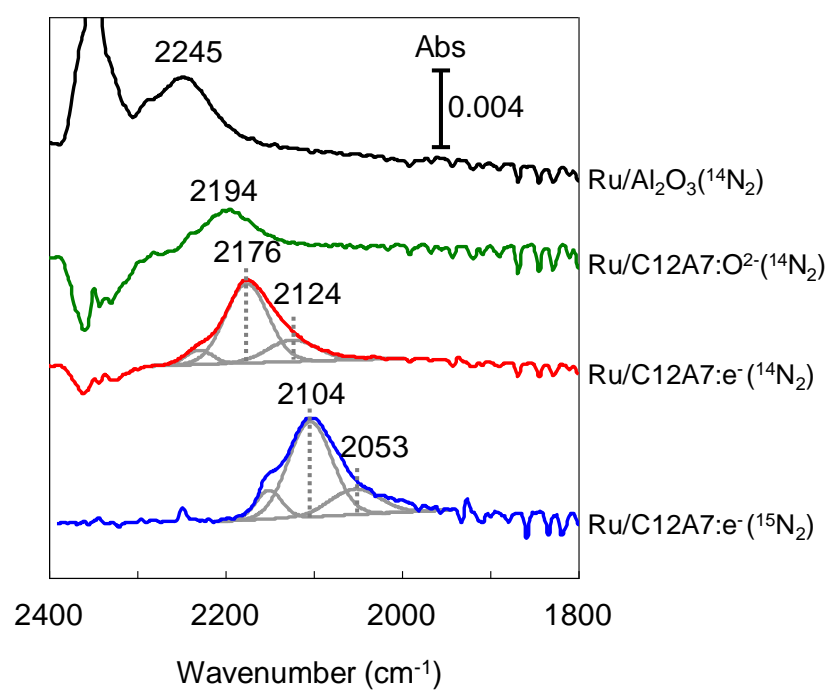

Fig. 5 Difference FT-IR spectra of $\mathrm{N}_{2}$ molecules before and after $\mathrm{N}_{2}$ adsorption on $\mathrm{Ru} / \mathrm{Al}_{2} \mathrm{O}_{3}\left({ }^{14} \mathrm{~N}_{2}\right.$, black), $\mathrm{Ru} / \mathrm{C} 12 \mathrm{~A} 7: \mathrm{O}^{2-}\left({ }^{14} \mathrm{~N}_{2}\right.$, green), $\mathrm{Ru} / \mathrm{C} 12 \mathrm{~A} 7: \mathrm{e}^{-}\left({ }^{14} \mathrm{~N}_{2}\right.$, red) and $\mathrm{Ru} / \mathrm{C} 12 \mathrm{~A} 7: \mathrm{e}^{-}\left({ }^{15} \mathrm{~N}_{2}\right.$, blue $)$ at -170 ${ }^{\circ} \mathrm{C}$ under $5 \mathrm{kPa}$ of $\mathrm{N}_{2}$.

して注入されると仮定すると、 Ru/C12A7: $\mathrm{e}^{-}(0.2 \mathrm{~g})$ の全て の電子が消費されたとしても生成されるアンモニアは 452 $\mu \mathrm{mol}$ 程度である。Fig. 4 の結果から実際に生成したアンモ ニアは $35 \mathrm{mmol}$ であることから、ケージ内の電子は反応中 に繰り返し使われていることがわかった。XRD や TEM 観 察の結果から、反応前後の C12A7: $\mathrm{e}^{-}$の結晶構造や、 Ru 粒 子サイズに変化がないことも確認している。

$\mathrm{C} 12 \mathrm{~A} 7 \mathrm{e} \mathrm{e}^{-}$から $\mathrm{Ru}$ へ電子注入による $\mathrm{N}_{2}$ 解離の促進を 調べるため、 $\mathrm{Ru}$ 上に分子上で吸着した $\mathrm{N}_{2}$ の FT-IR スペク
トルを測定した。通常気相の $\mathrm{N}_{2}$ 分子の伸縮振動 $\left(2331 \mathrm{~cm}^{-1}\right)$ はIRでは観察されないが、秋鹿らが報告しているように $\mathrm{Ru}$ 触媒上に end-on 型に吸着した窒素種は $2331 \mathrm{~cm}^{-1} よ り も$ 低波数側に観察され、 $\mathrm{Ru}$ からの電子注入を強く受けている 試料ほど低波数側へシフトすることが報告されている ${ }^{19)} 。$ Fig. 5 に様々な Ru触媒上に液体窒素温度で $\mathrm{N}_{2}$ を吸着させ た時の FT-IR スペクトルを示す。 $\mathrm{Ru} / \mathrm{Al}_{2} \mathrm{O}_{3}$ では $2245 \mathrm{~cm}^{-1}$ に 吸着窒素に由来するピークが観察された。この值は、文献 值ともよく一致する。一方、 $\mathrm{Ru} / \mathrm{C} 12 \mathrm{~A} 7: \mathrm{O}^{2-}$ に吸着した $\mathrm{N}_{2}$ は $2194 \mathrm{~cm}^{-1}$ に観察された。このことから $\mathrm{C} 12 \mathrm{~A} 7: \mathrm{O}^{2-}$ は、 $\mathrm{Al}_{2} \mathrm{O}_{3}$ よりも塩基性が強い担体であることがわかった。 $\mathrm{Ru} /$ C12A7: e-は、黑色の粉体であり、IR 光を透過しないため電 子濃度を $1 / 4$ 程度 $\left(5.0 \times 10^{20} \mathrm{~cm}^{-3}\right)$ に薄めた試料で測定を行っ た。 $\mathrm{Ru} / \mathrm{C} 12 \mathrm{~A} 7: \mathrm{e}^{-}$に吸着した $\mathrm{N}_{2}$ はさらに低波数側 (2230$\left.2030 \mathrm{~cm}^{-1}\right)$ に観察されることから、C12A7: e-からの電子注 入によって $\mathrm{Ru}$ 上に吸着した $\mathrm{N}_{2}$ の結合が弱められることが 明らかとなった。またこのピークは、2234、2176、2124 cm-1 の 3 つに波形分離され、それぞれ酸化した $\mathrm{Ru}$ 上の $\mathrm{N}_{2} 、 \mathrm{Ru}-$ C12A7: $\mathrm{e}^{-}$界面から離れた $\mathrm{Ru}$ 上の $\mathrm{N}_{2} 、 \mathrm{Ru}-\mathrm{C} 12 \mathrm{~A} 7$ : $\mathrm{e}^{-}$界面付 近の $\mathrm{Ru}$ 上の $\mathrm{N}_{2}$ に由来すると考えられる。触媒活性の担持 量依存性の結果と合わせて考えると、界面付近に吸着した $\mathrm{N}_{2}$ ほど C12A7: e-からの電子注入の影響を強く受け $\mathrm{N} \equiv \mathrm{N}$ 結合がより弱まることが考えられるためである。また、 Ru$\mathrm{Cs}-\mathrm{MgO}$ 上に吸着した窒素種の IR スペクトルの研究では、 Cs の担持量の増加とともに低波数側のピーク強度が強くな ることが知られており、電子供与剤近傍の $\mathrm{Ru}$ 上に吸着し た窒素分子がより低波数側に観測されることが報告されて いる ${ }^{19)}$ 。次に、 $\mathrm{Ru} / \mathrm{C} 12 \mathrm{~A} 7: \mathrm{e}^{-}$上に同位体窒素 $\left({ }^{15} \mathrm{~N}_{2}\right)$ を吸着 させると、3つのピークはそれぞれ $70 \mathrm{~cm}^{-1}$ 程度低波数側に 現れた。同位体効果によるピークシフトはそれぞれ下記の ように計算される。

$$
\begin{aligned}
& 2234 \mathrm{~cm}^{-1} \times(28 / 30)^{1 / 2}=2158 \mathrm{~cm}^{-1} \\
& 2176 \mathrm{~cm}^{-1} \times(28 / 30)^{1 / 2}=2102 \mathrm{~cm}^{-1} \\
& 2124 \mathrm{~cm}^{-1} \times(28 / 30)^{1 / 2}=2052 \mathrm{~cm}^{-1}
\end{aligned}
$$

上記の計算值と、Fig. 5 に示す観測值がほぼ一致するこ とからこれらのピークはいずれも $\mathrm{Ru} / \mathrm{C} 12 \mathrm{~A} 7: \mathrm{e}^{-}$上に吸着し た $\mathrm{N}_{2}$ に由来するものであることがわかる。

このように FT-IRの結果から、C12A7: $\mathrm{e}^{-}$から Ruへの電 子注入によって、 $\mathrm{N}_{2}$ の解離が促進されることが明らかと なったが、文献等では、 $\mathrm{Cs}-\mathrm{Ru} / \mathrm{MgO}$ 上に吸着した窒素種は 最大で $1910 \mathrm{~cm}^{-1}$ まで $\mathrm{N}_{2}$ のピークがシフトすることが報告 されている ${ }^{19)}$ 。吸着窒素に由来するピークは、触媒の前処 理条件や測定条件によって同じ触媒でも多少ピークトップ が変化することが報告されており ${ }^{20)}$ 、文献值との厳密な比 較は難しいが、FT-IRの結果から Cs-Ru/MgO と Ru/C12A7: $\mathrm{e}^{-}$との触媒活性の違いを十分に説明することができない。 
Table 2 Catalytic performance of Ru catalysts on various supports for isotopic exchange reaction of $\mathrm{N}_{2}$.

\begin{tabular}{cccc}
\hline Catalyst & $\begin{array}{c}\text { Catalytic } \\
\text { activity } \\
\left(\mathrm{mmol} \mathrm{g}^{-1} \mathrm{~h}^{-1}\right)\end{array}$ & TOF $\left(\mathrm{s}^{-1}\right)$ & $\begin{array}{c}\text { Activation } \\
\text { energy } \\
\left(\mathrm{kJ} \mathrm{mol}^{-1}\right)\end{array}$ \\
\hline $\mathrm{Ru} / \mathrm{C} 12 \mathrm{~A} 7 \mathrm{e}^{-}$ & 2.73 & 0.195 & 58.6 \\
$\mathrm{Ru}$ & 1.33 & 0.003 & 138.8 \\
\hline
\end{tabular}

${ }^{a}$ Reaction conditions: catalyst $(0.5 \mathrm{~g})$, reaction temperature $\left(360{ }^{\circ} \mathrm{C}\right)$, pressure $(20 \mathrm{kPa})$.

そこで、アンモニア合成反応と同じ反応温度での $\mathrm{N}_{2}$ と触 媒との相互作用を $\mathrm{N}_{2}$ の同位体交換反応を行うことにより 調べた。これは古くから尾崎らによって精力的に研究され た方法であり、(1) 式のように質量数の異なる $\mathrm{N}_{2}$ の混合ガ 又䨌囲気で触媒を加熱し、生成する質量数 29 の $\mathrm{N}_{2}$ を調べ ることで窒素の解離速度を調べる方法である ${ }^{21)}$

$$
{ }^{28} \mathrm{~N}_{2}+{ }^{30} \mathrm{~N}_{2}={ }^{29} \mathrm{~N}_{2}
$$

Table 2 に様々な触媒を用いて $\mathrm{N}_{2}$ の同位体交換反応を 行った結果を示す。Cs- Ru/ $\mathrm{MgO}(\mathrm{Ru}: 6 \mathrm{wt} \%)$ と比較して、 単位重量当たりの触媒活性が Ru/C12A7: $\mathrm{e}^{-}(\mathrm{Ru}: 2 \mathrm{wt} \%)$ の 方が高く、TOF に関しては 60 倍以上高い值を示すことが 明らかとなった。さらに、 $\mathrm{N}_{2}$ 同位体交換反応の活性化エネ ルギーに関しても $\mathrm{Ru} / \mathrm{C} 12 \mathrm{~A} 7: \mathrm{e}^{-}$は、Cs-Ru/MgO の半分の 值であることから、アンモニア合成反応の律速段階である 窒素の解離を促進することで高いアンモニア合成活性を示 すことが明らかとなった。

$\mathrm{Ru} / \mathrm{C} 12 \mathrm{~A} 7 \mathrm{e} \mathrm{e}^{-}$上でのアンモニア合成の反応機構を調べる ため、反応速度の窒素及び水素の分圧依存性を測定し、速 度論的解析を行った (Fig. 6, Table 3)。既報のどの触媒にお いても窒素に対する次数はほぼ +1 次であるが、 Ru/C12A7: $\mathrm{e}^{-}$は窒素に対する次数がおよそ +0.5 次であり、窒素の解離 が起こりやすくなっていることが速度論的にも示された。 さらに、多くの $\mathrm{Ru}$ 触媒は $\mathrm{Ru}$ 上に解離吸着した水素種が表 面を覆い、窒素の吸着を阻害するため (水素被毒)、水素に 対する次数が負の值を示している。既報の論文では、La、 $\mathrm{Sm} 、 \mathrm{Ce}$ 等の酸化物を添加すると水素被毒されにくくなるこ とが報告されている ${ }^{18,22)}$ 。しかし、表にも示すとおり、水 素次数が 0 に近づく程度である。一方、 $\mathrm{Ru} / \mathrm{C} 12 \mathrm{~A} 7: \mathrm{e}^{-}$は水 素の次数が +1 次であり、水素被毒に抗してアンモニアを生 成できることが見出された。C12A7: e-は、水素雲囲気で加 熱するとケージ内の電子の一部が水素と置き換わり、 $\mathrm{H}^{-}$と してケージ内にトラップされることが分かっている ${ }^{23)}$ 。従っ て、 $\mathrm{Ru}$ 上に解離吸着した水素種は速やかに $\mathrm{H}^{-}$としてケー

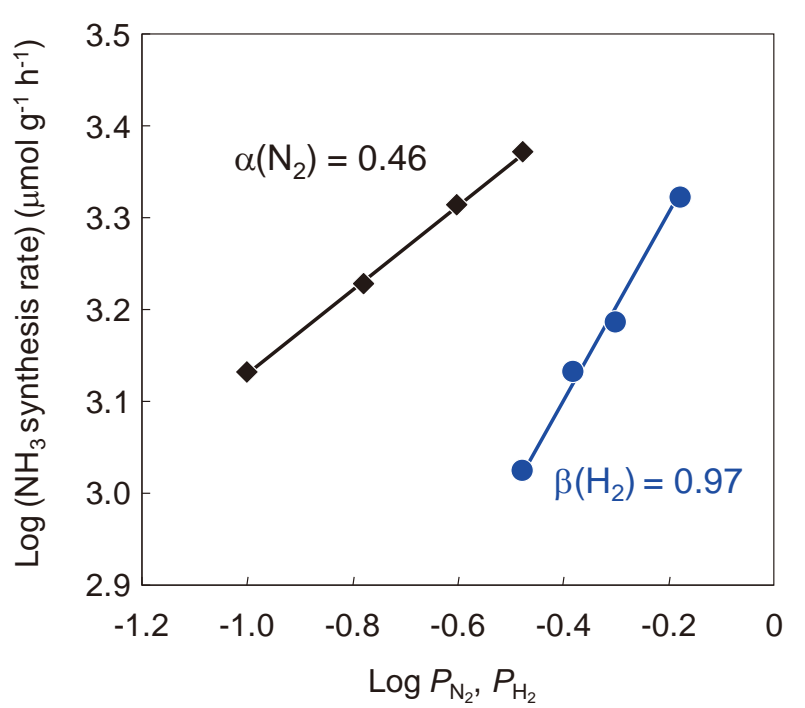

Fig. 6 Dependence of $\mathrm{NH}_{3}$ synthesis rate on the partial pressures of $\mathrm{N}_{2}$ and $\mathrm{H}_{2}$ on $\mathrm{Ru} / \mathrm{C} 12 \mathrm{~A} 7: \mathrm{e}^{-}$at $360{ }^{\circ} \mathrm{C}$ under atmospheric pressure and a total flow rate of $60 \mathrm{~mL} \mathrm{~min}^{-1}$.

Table 3 Orders of reaction for ammonia synthesis over various $\mathrm{Ru}$ catalysts $^{a}$.

\begin{tabular}{ccccc}
\hline Catalyst & $\alpha\left(\mathrm{N}_{2}\right)$ & $\beta\left(\mathrm{H}_{2}\right)$ & $\gamma\left(\mathrm{NH}_{3}\right)$ & Reference \\
\hline $\mathrm{Ru} / \mathrm{C} 12 \mathrm{A7}: \mathrm{e}^{-}$ & 0.46 & 0.97 & -1.0 & this work \\
$\mathrm{Ru} / \mathrm{C} 12 \mathrm{~A} 7: \mathrm{O}^{2-}$ & 1.00 & 0 & -0.25 & this work \\
$\mathrm{Ru} / \mathrm{MgO}$ & 0.82 & -0.38 & -0.68 & this work \\
$\mathrm{Ru}-\mathrm{Cs} / \mathrm{MgO}$ & 1.0 & -0.45 & -0.37 & this work \\
$\mathrm{Ru} / \mathrm{MgO}$ & 0.8 & -0.5 & -0.6 & Angew. chem. Int. Ed. 40, 1061, (2001) \\
$\mathrm{Ru}-\mathrm{Cs} / \mathrm{MgO}$ & 1.0 & -1.2 & -0.1 & J. Catal. 214, 327, (2003) \\
$\mathrm{Ru}-\mathrm{La} / \mathrm{MgO}$ & 0.85 & -0.15 & -0.17 & J. Catal. 225, 359, (2004) \\
$\mathrm{Ru} / \mathrm{CeO}{ }_{2}$ & 0.80 & -0.06 & -0.48 & Chem. Lett.1, 3, (1996) \\
$\mathrm{Ru} \mathrm{powder}$ & 0.96 & -0.72 & -0.15 & Appl. Catal. 28, 57, (1986) \\
$\mathrm{Co}{ }_{3} \mathrm{Mo}{ }_{3} \mathrm{~N}$ & 0.99 & 0.8 & -1.34 & Appl. Catal. 218, 121, (2001) \\
$\mathrm{Fe}(\mathrm{KM} 1)$ & 0.9 & 2.2 & -1.5 & J. Catal. 214, 327, (2003) \\
\hline
\end{tabular}

${ }^{a}$ Where the rate expression is $r=k P_{\mathrm{N}_{2}}^{\alpha} P_{\mathrm{H}_{2}}^{\beta} P_{\mathrm{NH}_{3}}^{\gamma}$

ジ内にトラップされるため水素被毒を受けないと考えられ る。このような特徴を有することから、加圧条件下での反 応において触媒活性が向上したと考えられる(Fig. 3)。また、 アンモニア合成反応後の $\mathrm{Ru} / \mathrm{C} 12 \mathrm{~A} 7: \mathrm{e}$ 触媒を窒素のみの䨌 囲気下で加熱するとアンモニアが生成するため、ケージ内 の $\mathrm{H}^{-}$は $\mathrm{Ru}$ 上で解離した窒素種と反応することも明らかと なった。以上の結果から考えられる反応機構を Fig. 7 に示 す。C12A7: $\mathrm{e}^{-}$ケージ内の電子は $\mathrm{Ru}$ 触媒へ注入され、 $\mathrm{Ru}$ 上 に吸着した窒素分子の反結合性軌道への電子供与が促進さ 


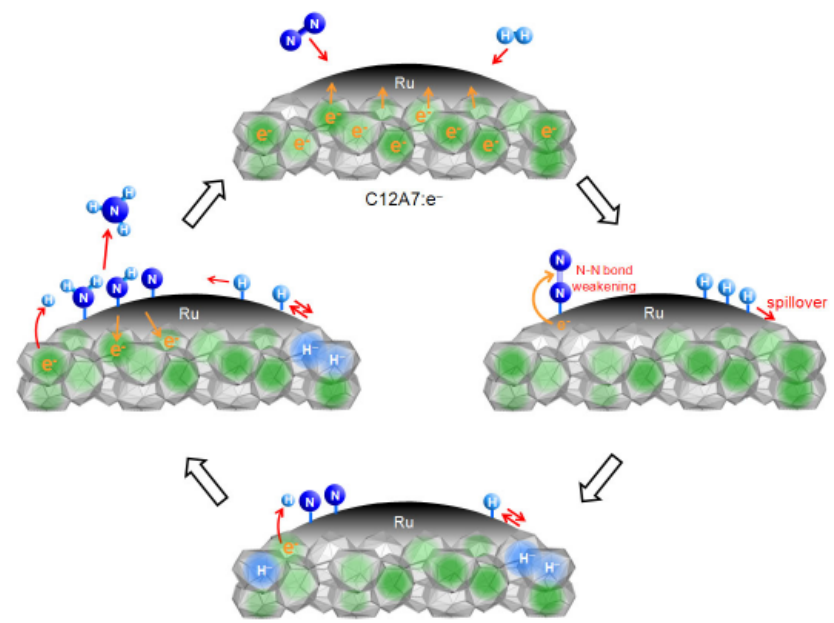

Fig. 7 Possible pathway for the ammonia synthesis reaction over $\mathrm{Ru} /$ C12A7: $\mathrm{e}^{-}$

れる。その結果として、窒素の解離が促進される。また、 $\mathrm{Ru}$ 表面で解離吸着した水素種は、担体の C12A7: $\mathrm{e}^{-}$ヘスピ ルオーバーし、電子と反応することで $\mathrm{H}^{-}$としてラップさ れる。 $\mathrm{Ru}$ と C12A7: e との界面付近では窒素の解離が特に 速いため $\mathrm{H}^{-}$と解離窒素分子が速やかに反応してアンモニア を生成する。この間、電子は元に戻るため触媒的に反応が 進行すると考えられる。

\section{4. おわりに}

アンモニア合成は、ハーバー・ボッシュらによって見い だされた優れた触媒技術が存在するため、これまでにない 全く新しい概念の触媒技術が生み出されない限り、新しい 技術と置き換わることはないであろう。しかし、エネルギー キャリアとして水素が注目されている現在、新たなアンモ ニア合成触媒を生み出すことは、学術的にも工業的にも重 要な意義を持つ。C12A7 エレクトライドを使ったアンモニ ア合成触媒では、高表面積化、Ruに替わる安価な金属の検 討、新たなアンモニア製造プロセスの構築など実際に使う 上ではまだまだ課題が残されているが、この分野の発展に 大きく寄与するものと期待している。現在、C12A7 エレク トライドが持つユニークな性質を活かしアンモニア合成以 外の反応の探索も行っている。最近では、アンモニア分解 反応に対しても優れた触媒性能を示すことを見いたした ${ }^{24)} 。$ また、2 次元構造を有するエレクトライドとして $\mathrm{Ca}_{2} \mathrm{~N}$ が発 見されている ${ }^{25)}$ 。このように、電子化物は触媒としての可 能性を秘めており、新たな触媒系の構築につながると考え ている。
謝 辞

本研究は、JSPS FIRST プログラムによって実施されたも のである。また、研究の一部は MEXT 元素戦略プログラム (拠点形成型）の支援を受けた。

\section{引用文献}

1) A. Mittasch: Adv. Catal., 2, 81 (1950).

2) T. Hikita, Y. Kadowaki, K. Aika: J. Phys. Chem., 95, 9396 (1991).

3) N. D.Spencer, R. C. Schoonmaker, G. A. Somorjai: Nature, 294, 643 (1981).

4) K. Aika, H. Hori, A. Ozaki: J. Catal., 27, 424 (1972).

5) C. J. H. Jacobsen, S. Dahl, B. S. Clausen, S. Bahn, A. Logadottir, J. K. Nørskov: J. Am. Chem. Soc., 123, 8404 (2001).

6) T. W. Hansen, J. B. Wagner, P. L. Hansen, S. Dahl, H. Topsøe, C. J. H. Jacobsen: Science, 294, 1508 (2001).

7) F. W. Bergstrom, W. C. Fernelius: Chem. Rev, 12, 43 (1933).

8) M. Kitano, Y. Inoue, Y. Yamazaki, F. Hayashi, S. Kanbara, S. Matsuishi, T. Yokoyama, S.-W. Kim, M. Hara, H. Hosono: Nat. Chem., 4, 934 (2012).

9) S. W. Kim, H. Hosono: Philos. Mag., 92, 2596 (2012).

10) S. Matsuishi, Y. Toda, M. Miyakawa, K. Hayashi, T. Kamiya, M. Hirano, I. Tanaka, H. Hosono: Science, 301, 626 (2003).

11) A. Ellaboudy, J. L. Dye, P. B. Smith: J. Am. Chem. Soc., 105, 6490 (1983).

12) J. L. Dye, Science, 301, 607 (2003).

13) P. V. Sushko, A. L. Shluger, M. Hirano, H. Hosono: J. Am. Chem. Soc., 129, 942 (2007).

14) Y. Toda, H. Yanagi, E. Ikenaga, J. J. Kim, M. Kubota, S. Ueda, T. Kamiya, M. Hirano, K. Kobayashi, H. Hosono: Adv. Mater, 19, 3564 (2007).

15) Y. Toda, Y. Kubota, M. Hirano, H. Hirayama, H. Hosono: ACS Nano, 5, 1907 (2011).

16) F. Rosowski, A. Hornung, O. Hinrichsen, D. Herein, M. Muhler, G. Ertl: Appl. Catal. A, 151, 443 (2001).

17) C. Liang, Z. Wei, Q. Xin, C. Li: Appl. Catal. A, 208, 193 (2001).

18) S. E. Siporin, R. J. Davis: J. Catal., 225, 359 (2004).

19) J. Kubota, K. Aika: J. Phys. Chem., 98, 11293 (1994).

20) Z. You, K. Inazu, K. Aika, T. Baba: J. Catal., 251, 321 (2007).

21) Y. Morikawa, A. Ozaki: J. Catal., 12, 145 (1968).

22) Y. Niwa, K. Aika: J. Catal., 162, 138 (1996).

23) K. Hayashi, S. Matsuishi, T. Kamiya, M. Hirano, H. Hosono: Nature, 419, 462 (2002).

24) F. Hayashi, Y. Toda, Y. Kanie, M. Kitano, Y. Inoue, T. Yokoyama, M. Hara, H. Hosono: Chem. Sci., 4, 3124 (2013).

25) K. Lee, S. W. Kim, Y. Toda, S. Matsuishi, H. Hosono: Nature, 494, 336 (2013). 